\title{
CD24 Gene
}

National Cancer Institute

\section{Source}

National Cancer Institute. CD24 Gene. NCI Thesaurus. Code C68585.

This gene is involved in the immune responsiveness of B-cells. 